\title{
INDIGENOUS HUNTING IN INDONESIAN NEW GUINEA: CULTURAL IDENTITY, FOOD SECURITY AND INCOME OPPORTUNITIES
}

\author{
Agustina Y. S. AROBAYA ${ }^{1)}$, DenY A. IYAI $^{2)}$, JOHAN F. KOIBUR ${ }^{2)}$, MARTHA KAYADOE ${ }^{3)}$ AND FREDDY \\ PATTISELANNO ${ }^{2 *}$ \\ ${ }^{1)}$ Faculty of Forestry Universitas Papua, Manokwari, UNIPA Campus, Jl. Gunung Salju Amban, Manokwari 98314 - \\ Papua Barat \\ ${ }^{2)}$ Faculty of Animal Science, Universitas Papua, Manokwari, UNIPA Campus, Jl, Gunung Salju Amban, Manokwari \\ 8314 - Papua Barat
}

*Email: f.pattiselanno@unipa.ac.id

Accepted November 04, 2021 / Approved December 27, 2021

\begin{abstract}
Wildlife hunting is important in satisfying people's need for meat as a source of dietary protein as well as being of economic value to the studied communities. Many people in Indonesian New Guinea rely on the benefits obtained from the extraction of plants and animals in the tropical forests, including hunting. This review aims to synthesise existing knowledge and identify areas that are fundamental to the body of knowledge on Indigenous hunting that has been integrated into many forest people societies in Indonesian New Guinea. People keep a relationship with nature by harmonising Indigenous hunting and cultural background. Available food source from wildlife and limited access to livestock were the major reason to acquire wild animals for consumption through hunting. Throughout of Indonesian New Guinea, the commercial hunting provide more opportunities for income generation. Indigenous hunting has long been part of cultural life of forest, providing a source of dietary protein to the household, and offer forms of income generation to the studied communities.
\end{abstract}

Key words: Culture, Food consumption, trade, Indigenous hunting, Indonesian New Guinea

\section{INTRODUCTION}

Tropical forest people in Africa and Southeast Asia have been hunting wildlife for food for at least 40,000 years (Bennett, 2002). In Latin America hunting has been carried out for at least 10,000 years. Many people across the tropics today continue the practice (Bennett, 2002). Wildlife hunting plays important role in satisfying people's need for meat as a source of dietary protein and fats, as well as being of economic value to rural communities. Hunting may also offer possibility of income opportunities through the sale of meat (MilnerGulland et al., 2003), obtaining traditional ingredients for human therapies and other forms of traditional uses (Williamson, 2002; Mockrin et al., 2005). Wild animals are also hunted to obtain trophies (skins, teeth, antlers and horns) that are used as cultural artefacts or for personal adornment (Fa and Brown, 2009).

Wildlife hunting is intimately linked to many cultures throughout the world's tropical forests. Apart from uses as a food source, Fa and Brown (2009) assert that hunting of wild animals can also be associated with obtaining medicine for human health and other traditional uses for example, most hard and soft body parts are used in some way. Throughout the Asian region, hunting of the native wildlife species is mostly conducted to provide the needs of traditional products for therapeutic process of particular diseases (Corlett, 2007). In Africa, some studies have identified other important roles of wildlife that have strong connections with differing cultures' spiritual health (Ntiamoa-Baidu,
1997). For instance, it is common that particular wildlife species were not hunted because they were considered sacred; they had special respect or sometimes were given special value for cultural and religious reasons. This phenomenon indicated the function of wildlife as totem species, tabooed species and sacrificial and/ or ceremonial species (Ntiamoa-Baidu, 1997). Acquisition of certain animal parts as cultural artifacts, for personal adornment or for hunting trophies is still a widespread and common practice throughout tropical forest regions and the rest of the world (Bennett and Robinson, 2000; $\mathrm{Fa}$ and Brown, 2009). The influence of culture plays a significant role in animal trophies obtained for cultural artifacts or for personal adornment in Papua New Guinea (Kwapena 1984).

New Guinea Island consists of Papua New Guinea in the east, while the half piece lies in the western part is Indonesian New Guinea. In this paper, Indonesian New Guinea refers to both Papua and West Papua Provinces. Many people in Indonesian New Guinea rely on the benefits obtained from the extraction of plants and animals in the tropical forests (Pattiselanno, 2004; Pattiselanno, 2006). Currently, limited access to domesticated meat and the availability of wild meat from the forest are major reasons for those who live in remote areas participating in hunting. Gathering and hunting activities conducted for the purpose of obtaining food and collecting ceremonial materials also play important roles in their traditional cultural life. 
There is also a tendency of hunting for wildlife to supply a market demand across the tropical forest areas around the world. The influence of market on wildlife hunting is well documented. Integration of hunting with the market for example, contributed significantly on indigenous hunting in the Ituri (Hart, 2000). Access to the market, lead to increase hunting on frequently hunted target species. The evidence suggests that hunting has increased over time due to the development of markets and the associated trade routes for most hunting preys in supplying regional and international trade networks. Thus, throughout much of Asia, the commercial wildlife trade is vast, and is now mainly supplying a luxury, urban market, both for meat as well as parts for traditional medicines (Bennett and Rao, 2002; Corlett, 2007). Pattiselanno et al. (2020) study describes the structure and operation of the wild meat trade chain and actors participating along the coast of the Bird's Head Peninsula (BHP) of West Papua, including how wild meat flows from forests to urban areas and contributes to local livelihoods across the trade chain.

There has been no review on indigenous hunting in Indonesian New Guinea, but evidence from other tropical forests suggests hunting linked to local culture, consumptions, and trading. The development of the Indonesian New Guinea are likely to transform local communities and the way they use forest resources, including wildlife.

Comparing the situation in Africa, South America and Asia with previous research from the island of New Guinea, particularly Indonesian New Guinea, hunting and trading of wild animals are clearly different in context. Each situation varies as a consequence of its unique ecological and cultural context. Notably, in the case of Indonesian New Guinea, there are few large native mammals and the largest potential hunting targets are introduced species, Rusa deer and pigs (Pattiselanno,
2006, 2012; Pangau-Adam et al., 2012). Cultural attitudes to consumption of animal species varies; thus, this study will further consider the importance of this difference and how it might contribute to the future biodiversity conservation in Indonesian New Guinea.

This review aims to synthesise existing knowledge and identify areas that are fundamental to understanding the contribution of Indigenous hunting, focusing on culture, food consumption and household income in the studied communities in Indonesian New Guinea. Throughout this paper, indigenous hunting refers to hunting of terrestrial wildlife by local ethnic groups (native Papuans) for various purposes including for consumption and trade.

In this study, data were obtained from previous studies on hunting in Indonesian New Guinea that have been published in national and international academic journals. Local communities involved in this study are Abun (Tambraw), Amberbaken (Tambaruw), Kebar (Tambrauw), Arfak (Pegunungan Arfak), Maybrat (Maybrat), Sebyar (Teluk Bintuni), Tembuni (Teluk Bintuni), and Bomberai (Fakfak), Napan (Nabire), Nimboran and Kemtugresik (Jayapura).

\section{Hunting and cultural identity}

In this study, hunting has been a long part of cultural identity for the native Papuans. This expresses through the use of wildlife for cultural artefacts, sacred species, hunting tenure and restricted time in hunting. Native Papuans acknowledge feather, skins and teeth as cultural artefacts (Figure 1a, b), which are utilized as parts of traditional costumes among different ethnic groups (MacKinnon, 1984; Beehler, 1985; Petocz, 1994). Hunting of wildlife for collecting cultural artefacts and personal adornment commonly practices across Papua New Guinea (Kwapena, 1984).

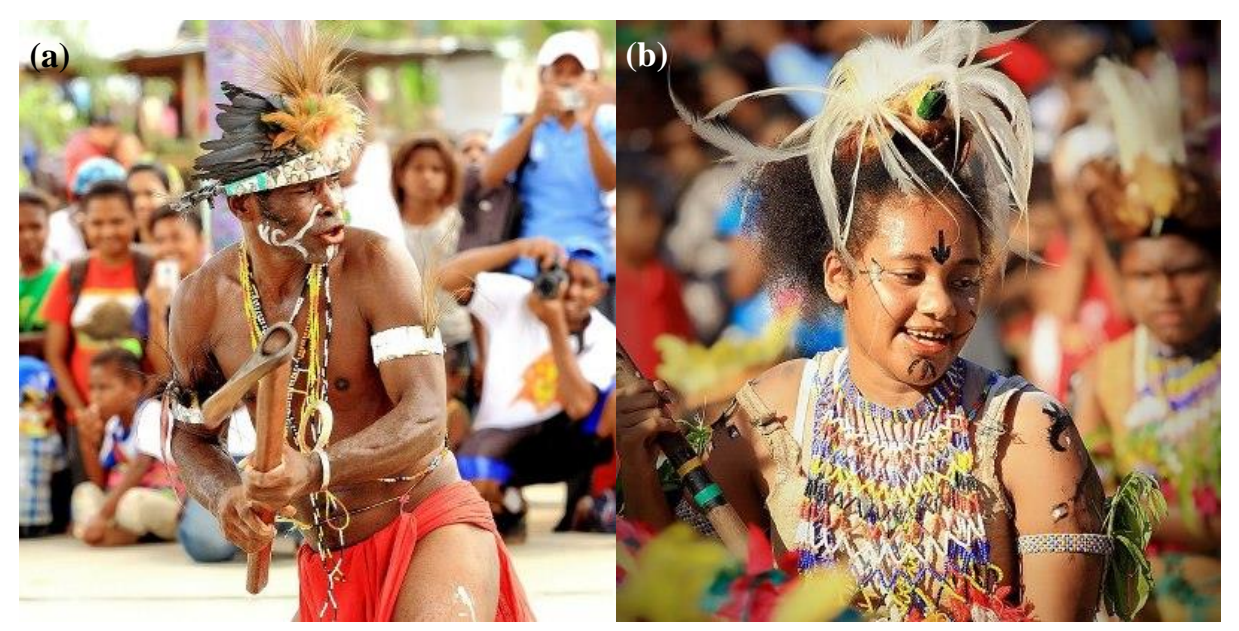

Figure 1.a. A male dancer with a combination of birds' feathers on his head; 1.b. A female dancer wearing traditional costume composed by wildlife from Kayu Pulo, Jayapura during the presentation of traditional dance in the Papuan Cultural Event (Picture by Geofrey Daimboa) 
In Indonesian New Guinea, a wide range of animals are hunted by different ethnic groups, and several species have been identified from different hunting sites. Although the hunting target varies among sites, wild pig and deer are the most commonly hunted species.

Some reasons that drive people's preferences on particular target species and one among them is relationship between the species and local culture. For example, particular species - pigeon and birds of paradise serve as religious symbol or their ancestor origins, were protected by a religious "tabu", that almost protected by all communities. They expressed the belief that local ancestors' origin from birds of paradise or pigeons; consequently, hunting of this species is prohibited. They were considered sacred, and people respect and give special value for cultural and religious reasons. This study indicates a strong connection between the local culture and animal species, specifically to taboo restrictions. Cultural reasons have been highly considered in selecting hunting target and all ethnic groups applied the limitation in selecting hunting target.

Another cultural practice is hunting tenure, where all groups controlled the tenure of areas where hunting are acceptable. All defined taboo or sacred forests were variable in size and depended on the land owned by each group. Forests are considered like a mother for the native Papuans (Pattiselanno and Arobaya, 2014), thus the loss of forests will lead to disenfranchisement of ethnic Papuans from their traditional landscapes and lifestyles. A forest, part of a forest, coast stretch, river, or pond may never be subjected to harvesting, hunting, fishing, or any other kind of resource use. Such areas are often protected by religious taboos and considered sacred to community members. In some sacred areas, all harvest and hunting activities are prohibited. It is also common to find restrictions of hunting to certain areas belonging to a clan. Hunting was forbidden in these areas, as they served as the abode of the departed spirits of ancestors. People also accepted that hunting could be performed only within the hunter's clan or tribe's tenure.
Time based restrictions on hunting were reported in many ethnic groups, with a number of variations in the nature of the customary law. Temporal or seasonal hunting are found with different approaches. People acknowledged open and closed hunting seasons known as 'sasi'. The practice was previously introduced in the marine harvest systems when missionaries from Moluccas (Nikijuluw 1995, Thorburn 2000).

Cultural approaches on hunting are varies among ethnic groups with similar purpose in hunting management based on the traditional ecological knowledge. From the conservation context, these approaches are applied from culture to nature in order to support wildlife conservation in Indonesian New Guinea.

\section{Hunting and food consumption}

Hunting purposes varies among communities, and hunting for consumption is among the purposes recognised. Available food source from wildlife and limited access to livestock products, driver people to look for the animal protein food sources from the forests. In all study sites, wildlife for food was obtained through hunting. Providing the household with complete meals including meat was important to the studied communities and we found that wildlife meat contributed to household consumption. Hunting preys that provide meat for consumption almost similar among ethnic groups, and they are deer (Cervus timorensis), wild pig (Sus scrofa), cuscus (Spilocuscus maculatus), bandicoot (Echymipera kalubu), tree kangaroo (Dendrolagus inustus), dusky pademelon (Thylogale brunii), monitor lizard, cassowary (Casuarius casuarius) and Papuan hornbill (Rhyticeros plicatus). Prescot-Allen and Prescot-Allen (1982) suggests that people in 62 countries are primarily dependent on wild animal meat as protein sources. Deer and wild pig meat were most commonly prepared for feast because they provided the largest amount of meat. Some native species such as cuscus and bandicoots (Figure 2.a., b), were also served as meat source for family consumption.

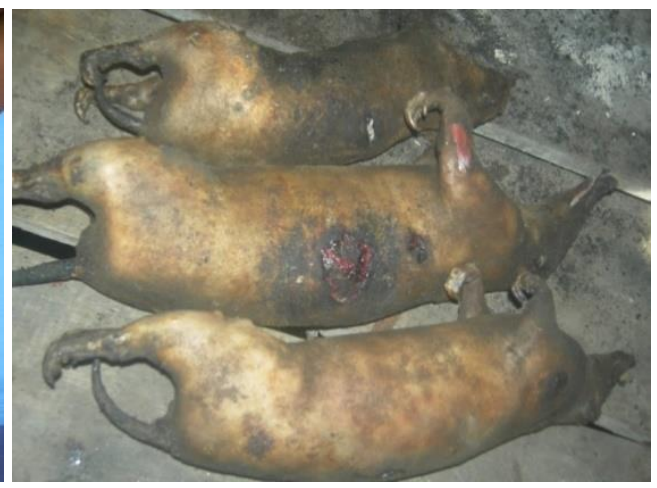

Figure 2.a. Cuscus is processed for consumption; 2.b. Feathers and skins of bandicoots are burned to clean before the meat is processed. 
In tropical areas world-wide, the meat of wild animals has long been part of the staple diet of forestdwelling peoples (Fa \& Yuste, 2001). Consumption of wild meat as a source of animal protein in rural areas is very important. The production of crop lands (tuber crops and bananas) satisfies people's needs for carbohydrates, but not for animal protein. Wild meat is not a luxury or resource they only turn to in times of hardship; it is a vital source of animal protein, and a commodity that can be sold. Pattiselanno and Lubis (2014) found that meals containing wildmeat was the most consumed meal, greater than meals containing fish, animal products and vegetables, and noodles in the Abun District of Tambrauw.

Cultural attitudes to consumption of animal species varies; Muslims not only avoid pork, but also other species if they are not certain that they are "clean". Our study also consider that this situation might impact hunting practices across Indonesian New Guinea. Recognising that there may be distinct regional differences in dietary habits, perhaps due to cultural influences, it seems reasonable to assume that variation in ethnic background may also lead to different dietary habits. In some sites, although hunting returns were sold for extra income, hunters kept some parts of the carcasses including head, bones, legs and intestines for family consumption. Consequently, although hunters sold meat to dealers they still kept some meat for family consumption. Therefore, the hunting prey benefit hunters for both consumption and trading purposes. In addition, Rao and McGowan (2002) indicated that wild meat contributes significantly to rural communities in Asia, Africa and Latin America because it is more easily accessible animal protein than cultivated meat, and is sometimes the dominant dietary protein available.

This study found that, using wildlife for food varies between communities we studied. Some people consume it because it is affordable, familiar, and depending on cultural background in each of the studied community. It was also discovered, that meat from wildlife as a highquality meal. In the study sites where access to domesticated meat are limited, it was difficult to have livestock meats in the menus. That is why people are relied on the easy access and available animal protein from the forests across the study sites.

\section{Hunting and income opportunities}

Hunting for gaining more income opportunities was also recognised as motivation for hunting in Indonesian New Guinea. Throughout the studied communities, meat from deer and wild pig were the most hunting that trading in all sites. They provided the largest amount of meat to supply wild meat to the consumers in surrounding villages and town.

The decision to hunt or trade wildlife depends not only on the hunter's nutritional and economic status, but also on the other opportunities available for food and income generation (Milner-Gulland et al., 2003). Thus, throughout much of Asia, the commercial wildlife trade is vast, but is now mainly supplying a luxury, urban market, both for meat as well as parts for traditional medicines (Bennett and Rao, 2002; Corlett, 2007).

Across the humid tropics, millions of people rely on using wildlife for an alternative source of family revenue. Research has found that the majority of those involved in wildlife trading belongs to low economic status households. Studies from different parts of the world revealed the significant contribution of wildlife as a source of cash for households living in extreme poverty (with daily per capita less than US\$1), particularly during lean agriculture seasons (Mendelson et al., 2003; Hilaluddin et al., 2005).

Wildlife products are valuable commodities, and wild meat is considered as premium value because it has a high value per unit weight compared with other forest products (Williamson, 2002). Wild meat was sometimes sold within a village or to other villages (Figure 3.a, b), or passed into the urban areas and sold at the local markets (Pattiselanno et al., 2020).

Local price per kilogram being 25,000 Indonesian Rupiah (IDR) (equals to US\$ 1.89) for venison (deer meat) and 15,000 IDR (or US\$1.13) for pork (wild pig meat) (Pattiselanno et al., 2019). We noticed the harvest rates of particular species were also more likely to be influenced by market demand and consumer preference for particular wild meat. Although there is no formal market for wildlife products, the sale of wild meat to traders provides cash to hunters. Conservation International Indonesia Program reported that several bird species and wildlife products such as antler and deer jerky were formally traded in traditional markets in Manokwari and Jayapura (Suryadi et al., 2004).

According to Pattiselanno et al. (2020), hunters, intermediaries, market traders, and restaurant owners are involved in longer-distance wild meat trade and their roles are well defined from hunting to trading. Wild meat was sold fresh, and the intermediaries operating in the study sites provided cool boxes to transport the meat to the market. Commercialization of wild meat along the coast of the BHP is less complicated than the market structures described in Africa and Latin America (Cowlishaw et al., 2005; Lescuyer and Nasi, 2016; Mendelson et al., 2003; Nielsen et al., 2016; van Vliet et al., 2015) because there are few intermediaries involved. 

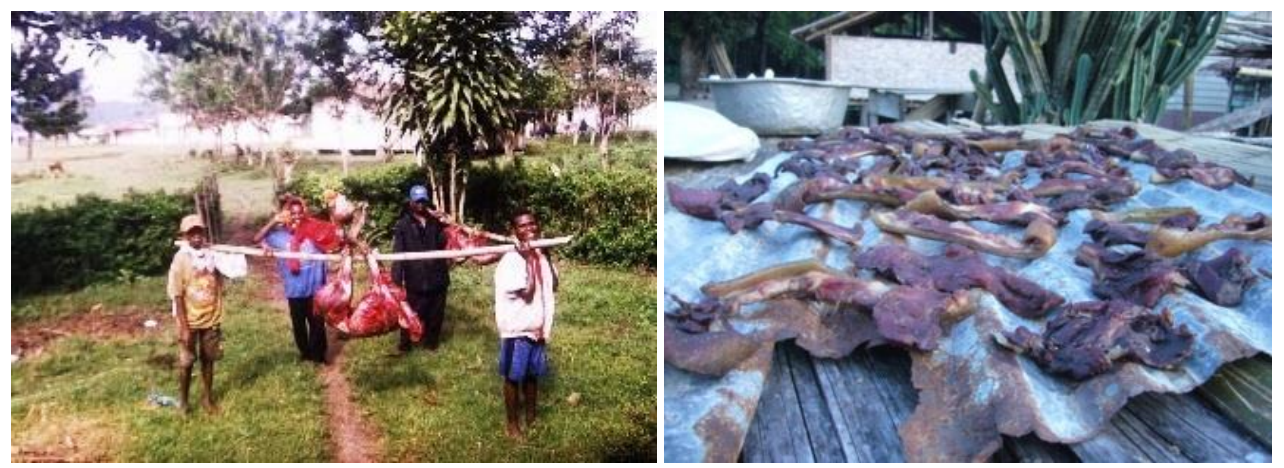

Figure 3.a. Villagers sold venison from house to house in Kebar of Tambrauw Regency; b. Venison is salted and sundried to produce jerky in Amberbaken of Tambrauw Regency.

This review indicates that, there is a tendency of shifting on livelihood options from subsistence-based to market-based, in which hunting is conducted to gain more cash income for the households. In contrast to studies in Africa and South America, the trade in this study was a relatively small economic activity. Though the scale of the trade has not yet been assessed, trading of wild meat play an important role to local livelihoods

\section{CONCLUSION}

Indigenous hunting has long been part of cultural life of forest communities in Indonesian New Guinea. Cultural approaches on hunting are varies among ethnic groups with relatively similar context for hunting management based on the traditional ecological knowledge. Using wildlife for food varies between communities we studied. People consume it because it is a free accessible source, cheap and link to cultural background of the studied communities. In the place where the domesticated meat are absence, people are more depending on the available animal protein sources from the forests. We observe the tendency of using wildlife for market-based, and hunting is conducted to gain more cash income for the households. Though the scale of the trade is still a relatively small economic, trading of wild meat play an important role to local livelihoods.

\section{REFERENCES}

Beehler B. 1985. Conservation of New Guinea rainforest birds. ICBP Technique Publication 4, 233-247.

Bennett EL, Robinson JG. 2000. Hunting for sustainability: the start of a synthesis. In JG Robinson, EL Bennett. Hunting for sustainability in tropical forests. (pp. 499-519) New York: Columbia University Press

Bennett EL, Rao M. 2002. Wild meat consumption in Asian tropical forest countries: Is this a glimpse of the future for Africa? In SA Mainka, M Trivedi. Links between biodiversity conservation, livelihoods and food security: The sustainable use of wild species for meat. (pp. 39-44). Switzerland and Cambridge, UK: IUCN, Gland.

Bennett EL. 2002. Is there a link between wild meat and food security? Conservation Biology 16(3), 590-592.

Corlett RT. 2007. The impact of hunting on the mammalian fauna of tropical Asian forests. Biotropica 39(3), 292-303.

Cowlishaw G, Mendelson S, Rowcliffe JM. 2005. Structure and operation of a bushmeat commodity chain in Southwestern Ghana. Conservation Biology 19(1), 139-149.

Fa JE, Brown D. 2009. Impacts of hunting on mammals in African tropical moist forests: a review and synthesis. Mammal Review 39(4), 231-264.

Fa JE, Yuste JEG. 2001. Commercial bushmeat hunting in the Monte Mitra forests, Equatorial Guinea: extent and impact. Animal Biodiversity and Conservation 24(1), 31-52.

Hart JA. 2000. Impact and sustainability of indigenous hunting in the Ituri Forest, Congo-Zaire: A comparison of unhunted and hunted duiker populations. In Robinson JG, Bennett EL. Hunting for sustainability in tropical forests. (pp. 106-153) New York: Columbia University Press.

Hilaluddin, Kaul R, Ghose D. 2005. Conservation implications of wild animal biomass extractions in Northeast India. Animal Biodiversity and Conservation, 28(2), 169-179.

Iyai DA. 2002. Sistim perburuan dan pemanfaatan Biawak (Varanus spp) oleh masyarakat desa Yaur Kecamatan Yaur Kabupaten Nabire. Unpublished undergraduate thesis, Universitas Negeri Papua Manokwari, Indonesia.

Kwapena N. 1984. Traditional conservation and utilization of wildlife in Papua New Guinea. The Environmentalist 4(7), 22-26.

Lescuyer G, Nasi R. 2016. Financial and Economic Values of Bushmeat in Rural and Urban Livelihoods in Cameroon: Inputs to the Development of Public Policy. Internaotional Forestry Review 18:9

MacKinnon K. 1984. Alam Asli Indonesia Flora, Fauna dan Keserasian. Jakarta: PT Gramedia.

Mendelson S, Cowlishaw G, Rowcliffe JM. 2003. Anatomy of a bushmeat commodity chain in 
Takoradi, Ghana. The Journal of Peasant Studies 31(1), 73-100.

Milner-Gulland EJ, Clayton L. 2002. The trade in babirusas and wild pigs in North Sulawesi, Indonesia. Ecological Economics 42, 165-183.

Mockrin MH, Bennett EL, La Bruna DT. 2005. Wildlife farming: a viable alternative to hunting in tropical forests? WCS Working Paper No. 23. New York: Wildlife Conservation Society.

Nielsen MR, Meilby H, Smith-Hall C. 2016. How could the Bushmeat Tradein the Kilombero Valley of Tanzania be Regulated? Insights from the Rural Value Chain. Oryx:84-93. DOI:10.1017/ S003060531400009X.

Nikijuluw, V. P. H. 1995. Community-based fishery management (Sasi) in Maluku. Indonesian Agricultural Research and Development Journal 17: 33-39.

Ntiamoa-Baidu Y. 1997. Wildlife and food security in Africa. FAO Conservation Guide 33. Rome: Food and Agriculture Organization of the United Nations.

Pangau-Adam, M., Noske, R. and Muehlenberg, M. (2012). Wildmeat or bushmeat? Subsistence hunting and commercial harvesting in Papua (West New Guinea), Indonesia. Human Ecology 40, 611-621.

Pattiselanno F. 2004. Wildlife utilization and food security in West Papua, Indonesia. Southeast Asian Regional Center for Graduate Study and Research in Agriculture (SEARCA) Agriculture and Development Seminar Series. Los Baños: SEARCA

Pattiselanno F. 2006. The wildlife hunting in Papua. Biota 11(1), 59-61.

Pattiselanno F, Arobaya AYS. 2014. The future of Papua's biodiversity is alarming. Jakarta Post 1 Dec 2014

Pattiselanno F, Lubis MI. 2014. Hunting at the Abun Regional Marine Protected Areas: A link between wildmeat and food security. Hayati Journal of Biosciences 21(4): 180-186

Pattiselanno F, Apituley JRM, Arobaya AYS, Koibur JF. 2020. Using wildlife for local livelihood Experiences from the Bird's Head Peninsula, West Papua, Indonesia. Biodiversitas 20(7): 1839-1845

Petocz RG. 1994. Mamalia Darat Irian Jaya. Jakarta: WWF Indonesia Program.

Prescott-Allen R, Prescott-Allen C. 1982. What's Wildlife worth? Washington: International Institute for Environment and Development.

Rao M, McGowan PJK. 2002. Wild-meat use, food security, livelihoods, and conservation. Conservation Biology 16(3), 580-583.

Suryadi S, Wijayanto A, Wahyudi M. 2004. Survey pasar/monitoring perdagangan hidupan liar di Kabupaten Jayapura dan Manokwari, Jakarta: Conservation International Indonesia dan Seksi Konservasi Sumberdaya Alam Wilayah Manokwari.

Thorburn, C.C. 2000. Changing Customary Marine Resource Management Practice and Institutions: The Case of Sasi Lola in the Kei Islands, Indonesia. World Development 28, 1461-1479

van Vliet N, Quiceno MP, Cruz D, de Aquino LJN, Yagüe B, Schor T, Hernandez S, Nasi R. 2015. Bushmeat Networks Link the Forest to the Urban Areas in the Trifrontier Region between Brazil, Columbia and Peru. Ecology and Society 20:21. DOI:10. 5751/ES-07782-200321.

Williamson D. 2002. Wild meat, food security and forest conservation. In SA Mainka, M Trivedi. Links between biodiversity conservation, livelihoods and food security: The sustainable use of wild species for meat. (pp. 19-22) Gland: International Union for Conservation of Nature. 